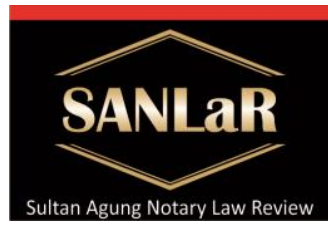

Volume 3 No. 1, March 2021
Sultan Aqung

Notary Law Review

Legal Review Concerning Summary...(Bima Pradana)
ISSN 2686-4428

published by

Master of Notarial Law

Universitas Islam Sultan Semarang

\title{
Legal Review Concerning Summary of Office of Notary \& Land Asset Officers Who Are Not Uniting Area of Work
}

\author{
Bima Pradana*) \\ *) Students of Master of Notary Law, Universitas Islam Sultan Agung (UNISSULA) \\ Semarang
}

\begin{abstract}
Notary is a promising legal profession. Of course there are some special competencies that must be met to become a notary. In other words, it is impossible for a notary to practice without having sufficient skills. Legal education background is a must. Postgraduate education in notary law must be preceded by taking a bachelor's degree in law. Notary is a public official who has the authority to make an authentic deed. This has been regulated in the provisions of Article 1 of the Law on the Position of Notary Public (hereinafter abbreviated as UUJN).
\end{abstract}

Keywords: Review; Land Asset Officers; Uniting Area.

\section{Introduction}

The position of Notary is also the position of a state official or public official, based on the provisions in the UUJN, a general official is a person who carries out some of the public functions of the state, especially in the field of civil law. A Notary is appointed and dismissed by the Minister of Law ${ }^{1}$ and Human Rights (Menkum HAM). The minister is also authorized to determine the Notary Position Formation in the regency or city as the seat of the Notary Public. A notary has an office area covering the entire province from his place of domicile and is obliged to have only one office, namely at his place of domicile and is not authorized to regularly carry out office outside his place of domicile.

The State Minister who appoints and dismisses a Notary and PPAT is also under different Ministries. Therefore, it is not uncommon for a Notary who has been appointed and has a certain work area / office area and wants to concurrently serve as a PPAT, after passing the exam, he turns out to be appointed as a PPAT for a work area / position area that is different from the work area / area of office as Notary Public².

Article 17 letter g No. 30 states that notaries are prohibited from holding concurrent positions outside the notary's area of office. Based on Article 85 UUJN, if the prohibition is violated, it can be subject to administrative sanctions from the MPN in stages, the Notary is first given the opportunity to defend

\footnotetext{
${ }^{1}$ Salim, H.S. (2015). Teknik Pembuatan Akta Satu Konsep Teoritis, Kewenangan Notaris, Bentuk dan Minuta Akta. Jakarta: PT Rajagrafindo Persada p.33.

${ }^{2}$ Tan Thong Kie. (2007). Studi Notariat dan Serba-Serbi Praktek Notaris. Jakarta : PT. Ichtiar Baru van Hoeve. p. 449
} 
himself starting from the Regional Supervisory Council (hereinafter abbreviated as MPD), the Regional Supervisory Council (hereinafter abbreviated as MPW), the Central Supervisory Council (hereinafter abbreviated as MPP) and in the end the MPP proposal would be disrespectfully dismissed by the Minister of Law and Human Rights of the Republic of Indonesia.

\section{Research methods}

The research approach used in this research is to use an empirical/sociological juridical review approach. The empirical juridical approach is a method of procedure used to solve problems by examining secondary data first, then continued by using research on primary data in the community or in the field. The empirical juridical method is used because it is an approach that is researched and the research results obtained in relation to its legal aspects. ${ }^{3}$

\section{Result and Discussion}

Article 9 paragraph (1) letter $d$ of the UUJN states that notaries are temporarily suspended from their positions due to violations of their obligations and position restrictions, so notaries who are different from the position of office as mentioned have violated the prohibition of office as stated in Article 17 letter $\mathrm{g}$ of the UUJN. With this incident, the Notary concerned must be temporarily suspended from his position for a maximum of 6 (six) months (Article 9 paragraph (4) UUJN). And before the dismissal is carried out, the Notary concerned is given the opportunity to defend himself in stages before the Supervisory Council (Regional, Regional and Central) see Article (Article 9 paragraph (2) and (3) UUJN.

Although in this case based on Article 10 paragraph (2) UUJN Notary who has been temporarily suspended from his position, he can be reappointed as Notary by the Minister after the temporary dismissal period ends. In this connection it is necessary to understand that being appointed as PPAT in a different area of office with a Notary is not temporary, but permanent, is it possible, by not changing (not moving) the Position Area, after the 6 (six) month period of temporary dismissal ends, it can be appointed back in the same position?

Where as in order for the same area of office to be the Notary Public and PPAT, can the Notary concerned resign from the previous position of office to be the same as PPAT? The answer is yes, but the problem is if it turns out, in the area of office (city / regency) there is no formation, of course it cannot be appointed as well, and vice versa, if the PPAT office area is moved to be adjusted to the notary office area, the problem is, is there a formation in the area concerned? If there is no formation, the end cannot be lifted either.

\footnotetext{
${ }^{3}$ Yunaldi. (2015). Usulan Penelitian, Program Magister IImu Hukum. Semarang: Unissula.p.30.
} 
Based on Government Regulation of the Republic of Indonesia Number 37 of 1998 concerning PPAT Position Regulations, in Article 8 paragraph (1) letter c, it is emphasized that PPAT ceases from its position as PPAT because it carries out its duties as a Notary in a city / regency area other than its working area as PPAT. Thus, those who pass as PPAT and have also carried out their duties as Notary Public are different from their positions as PPATs, the relevant PPAT will automatically stop being PPAT ${ }^{4}$.

Even though in this case based on Article 10 paragraph (2) UUJN Notary who has been temporarily suspended from his position, he can be reappointed as Notary by the Minister after the temporary dismissal period ends. In this connection it is necessary to understand that being appointed as PPAT in a different area of office with a Notary is not temporary, but permanent, is it possible, by not moving the Position of Office, after the 6 (six) month period of temporary suspension ends, it can be re-appointed in the territory of office the same ${ }^{5}$.

Where as in order to have the same position as the Notary Public and PPAT, can the Notary concerned resign from the old position area so that it is the same as PPAT? The answer is yes, but the problem is if it turns out, in the area of office (city / regency) there is no formation, of course it cannot be appointed as well, and vice versa, if the PPAT office area moved to be adjusted to the notary office area,

In another legal rule it is stated, that based on the Government Regulation of the Republic of Indonesia Number 37 of 1998 concerning PPAT Position Regulations, in Article 8 paragraph (1) letter $\mathrm{c}$, it is stated that PPAT resigns from its position as PPAT due to carrying out its duties as a Notary in city / regency areas other than his working area as PPAT. Therefore, those who pass as PPAT and have also carried out their duties as Notary Public are different from their positions as PPATs, the relevant PPAT will automatically stop being PPAT.

With such an incident, so that any defense to be made by the Notary before the Supervisory Council or before the National Land Agency is useless because the mistakes are clear and the arrangements are clear ${ }^{6}$.

As in Article 17 letter g UUJN, it is explained that notaries are prohibited from holding concurrent positions outside the notary's office area. If the prohibition is violated, then based on Article 85 UUJN, it can be subject to administrative sanctions from the Notary Supervisory Council in stages. Notaries are given the opportunity to defend themselves starting from the MPD, MPW, MPP, then finally the MPP proposal will be carried out Disrespectful dismissal by the Minister of Law and Human Rights. Republic of Indonesia. and then in Article 9

\footnotetext{
${ }^{4}$ Habib Adjie. (2013). Saksi Perdata dan Administratif Terhadap Notaris Sebagai Pejabat Publik. Bandung: Refika Aditama. p. 137.

${ }^{5}$ Sjaifurrachman and Habib Adjie. (2011). Aspek Pertanggungjawaban Notaris Dalam Pembuatan Akta. Bandung: Mandar Maju. p. 245

${ }^{6}$ Ibid.
} 
paragraph (1) letter $d$ of the UUJN, that a Notary has been temporarily suspended from his position for committing a violation of his obligations and prohibition of office.

That the Notary concerned must be temporarily suspended from his position for 6 (six) months (Article 9 paragraph (4) UUJN). Before the dismissal is carried out, the Notary concerned is given the opportunity to defend himself in stages before the Supervisory Council (Regional, Regional and Central) see Article 9 paragraph (2) and (3) UUJN. In this case, based on Article 10 paragraph (2) UUJN Notary who has been temporarily suspended from his position can be reappointed as Notary by the Minister after the termination of the temporary dismissal has ended ${ }^{7}$.

In accordance with article 8 paragraph (1) point c PP Number 38 of 1997 concerning PPAT Position Regulations, namely: "PPAT ceases to serve as PPAT because it is appointed and takes an oath of office or carries out duties as a Notary with a domicile in a region other than the working area as PPAT". It is clear that this article regulates the legal consequences in the event that a Notary Public / PPAT is appointed in a different position of office. This situation causes the PPAT concerned to automatically terminate itself as PPAT and therefore no decision to dismissal is required. The person concerned is no longer entitled to make deeds.

Article 9 "PPAT that stops serving as PPAT because of being appointed and taking the oath of office of a Notary in a Regency / Municipal Region other than its working area as referred to in Article 8 paragraph (1) letter c can be reappointed as PPAT with the working area of the Regency / Municipality of the Region where it works his position as a Notary, if the PPAT formation for the work area is not yet full".

In the event of a difference in working areas like that, the first action that can be taken is that the PPAT Candidate must be active in the BPN to immediately take care of the change in the work area being requested whether a SK has been issued or has not been issued a Decree on his appointment as PPAT. The concerned party immediately goes to the Central BPN to apply for changes to the work area following the Notary Work Area by attaching a Decree of his Appointment as Notary and Minutes of his Appointment as Notary ${ }^{8}$.

\section{Closing}

If it turns out that the work area being applied for is closed or there is no formation, then the concerned must wait until there is formation / evaluation of the area. The problem is waiting here in the sense that it cannot be determined how long and for how long. While waiting for certainty what can be done is that

\footnotetext{
${ }^{7}$ Soerjono Soekanto. (2004). Faktor-Faktor Yang Mempengaruhi Penegakan Hukum. Jakarta: Rajawali Press. p. 4.

${ }^{8}$ Rosa Agustina, et.al. (2012). Hukum Perikatan (Law of Obligations). Denpasar: Pustaka Larasan. p. 11
} 
the person concerned must make a choice, choose his work area as a Notary or his work area as PPAT, because as described above, a Notary / PPAT may not have a branch office / representative office and must have 1 (one) office who is domiciled in his working area and if the Notary serves concurrently as PPAT, the Notary's office will also become the PPAT office which he concurrently serves.

5. References

[1] Habib Adjie. (2013). Saksi Perdata dan Administratif Terhadap Notaris Sebagai Pejabat Publik. Bandung: Refika Aditama.

[2] Rosa Agustina, et.al. (2012). Hukum Perikatan (Law of Obligations). Denpasar: Pustaka Larasan.

[3] Salim, H.S. (2015). Teknik Pembuatan Akta Satu Konsep Teoritis, Kewenangan Notaris, Bentuk dan Minuta Akta. Jakarta: PT Rajagrafindo Persada

[4] Sjaifurrachman and Habib Adjie. (2011). Aspek Pertanggungjawaban Notaris Dalam Pembuatan Akta. Bandung: Mandar Maju.

[5] Soerjono Soekanto. (2004). Faktor-Faktor Yang Mempengaruhi Penegakan Hukum. Jakarta: Rajawali Press.

[6] Tan Thong Kie. (2007). Studi Notariat dan Serba-Serbi Praktek Notaris. Jakarta: PT. Ichtiar Baru van Hoeve.

[7] Yunaldi. (2015). Usulan Penelitian, Program Magister IImu Hukum. Semarang: Unissula. 